\title{
Re-designing university courses to support collaborative knowledge creation practices
}

\author{
Minna Lakkala, Auli Toom, Liisa Ilomäki, and Hanni Muukkkonen \\ University of Helsinki
}

\begin{abstract}
Higher education institutions should not only aim to educate academic experts who master their own fields, but also give their students generic skills important in contemporary society. New teaching methods are required to support the development of such skills. The study examined how a group of voluntary university lecturers re-designed their courses by applying theory-based pedagogical design principles emphasising object-oriented, collaborative knowledge creation supported by digital technology. The primary data consisted of lecturer interviews and students' written post-evaluations from three courses. The re-designed courses included broader thematic assignments, more cumulative knowledge production in groups and more diverse use of technology than prior course iterations. Both the lecturers and students addressed the learning outcomes in positive terms, but collaborative knowledge production was more evident in two courses designed according to authentic professional practices. Students generally valued the working methods, although they also pointed out weaknesses in the tasks, course structuring and group work. The lecturers experienced some difficulties in guiding students' productive group work. The pedagogical design principles worked well as conceptual tools in the intervention process, but they should be complemented with recommendations for teachers on modelling authentic professional practices and methods of scaffolding students' collaborative knowledge creation efforts.
\end{abstract}

\section{Introduction}

University science faculties emphasise that their central task is to educate academic experts who master their own fields, its core contents, methods and domain-specific skills. However, they should also take into account the fact that currently work life outside universities is rapidly changing and ensure that students acquire the more generic skills required to deal with these complex, ill-defined working contexts (Toom, 2012). Several researchers (Broussard, La Lopa, Joseph, \& Ross-Davis, 2007; Klusek \& Bernstein, 2006; Muukkonen \& Lakkala, 2009) have defined emerging competence requirements, such as harnessing the abilities of group works, networking, working in multidisciplinary teams, epistemic involvement, or dealing with uncertainty and confusion. Modern knowledge work focuses on advancing concrete knowledge objects (e.g., reports, models, presentation material) through the participants' collective efforts and resources (Bereiter, 2002; Knorr Cetina, 2001). In the present study, collaborative knowledge creation practices are seen as practices where people work intentionally and effectively both individually and together in solving ill-defined problems, co-regulating their work and creating novel solutions and new knowledge. In current university education, novel work-related competencies are not necessarily well addressed. For example, in two Finnish studies, young academics evaluated their working life skills as inadequate, reporting that they had only learnt the most important skills at work (Tynjälä, Slotte, Nieminen, Lonka, \& Olkinuora, 2006), or reported that they lacked competencies such as negotiation, organisation, teamwork, presentation, project management, and social skills (Lindholm, 2011). The Commission on Accountability in Higher Education (2005) reported that students leave higher education with insufficient abilities to solve open-ended problems. On the whole, there appears to be a mismatch between university education outcomes and the needs of the knowledge society (Klusek \& Bernstein, 2006).

Students' opportunities to learn generic work-related competencies during university studies depend on the characteristics of the learning environment and its educational methods. This calls for efforts from university lecturers to transform their course designs towards practices that expose students to collaborative knowledge practices. Numerous issues, such as inflexible curriculum frameworks, a lack of development partnerships, insufficient technological resources, or even the reluctance of students to adopt novel technologies or ways of working may hamper efforts to develop new teaching methods. In addition, theory-driven pedagogical models might be considered as being too abstract and idealistic to be applied in ordinary teaching contexts (Paavola, Lakkala, Muukkonen, Kosonen, \& Karlgren, 2011). The research 
evidence of Gibbs and Coffey (2004) indicated that the participation of university teachers in coherent, long-term pedagogical training programs has an effect on their pedagogical practices and their students' study approaches. Buus (2012) reported experiences from a development programme promoting the use of social media in problem-based learning, in order to emphasise more social, student-centred, collaborative and production-oriented pedagogical strategies. He concluded that it is important to support teachers both in the design and implementation of changes in their educational practices.

There exists a broad consensus among educational researchers (e.g., Marton \& Trigwell, 2000; Bereiter, 2002; Brooks \& Everett, 2009; Mills-Dick \& Hull, 2011) about the features of learning activities that would promote relevant competencies for the future, including: facing open-ended problems, utilisation of collective efforts, the rich use of modern technologies, encounters with real-world complexity through work life contacts; or developing pieces of work for some relevant use. These activities offer students possibilities to meet the authentic characteristics of knowledge work. Various types of tasks, such as teamwork, customer assignments, and project work have been employed (Denton \& McDonagh, 2005; Broussard et al., 2007; Muukkonen et al., 2013) to cultivate student learning in line with the requirements of the surrounding society. Also many pedagogical models have been suggested as good methods to promote generic competencies; for instance, problem-based learning (Prince, van Eijs, Boshuizen, van der Vleuten, \& Scherpbier, 2005), project-based learning (Helle, Tynjälä, \& Olkinuora, 2006), or inquirybased learning (Gilardi \& Lozza, 2009).

One promising approach is to define a set of design principles that can be used as heuristic guidelines for improving educational practice (Bell, Hoadley, \& Linn, 2004; Kali, Levin-Peled, \& Dori, 2009). The design principles may be based on theory or on empirical findings; theory-driven principles can be seen as defining conditions for ideal pedagogy on the basis of the theory in question (Lakkala, Ilomäki, Paavola, Kosonen, \& Muukkonen, 2012). Instead of selecting and applying a specific, fixed pedagogical model, design principles may help educational practitioners to evaluate, plan and revise their teaching practices in a more flexible way and adapt learning-theoretical perspectives to various settings and contexts. In the present study, theory-based pedagogical design principles were used as vehicles for change to inspire university lecturers in transforming their course designs towards practices that expose students to collaborative knowledge creation for developing competencies important in working life.

\section{Pedagogy promoting students' collaborative knowledge creation}

According to Paavola and Hakkarainen (2005), pedagogy emphasising collaborative knowledge creation represents the knowledge creation metaphor of learning, complementing the acquisition and participation metaphors introduced by Sfard (1998); learning is not only individual knowledge acquisition or adoption of existing social and professional practices, but also the creation of new knowledge and practices in collaboration with others. In order to explicate the core issues in the knowledge creation metaphor, Paavola and Hakkarainen (2005) introduced the trialogical approach to learning, in which the students' deliberate engagement in producing something concrete and meaningful together is considered as the third, essential aspect, in addition to individual efforts and community participation.

A set of design principles was developed to guide the implementation of the trialogical approach to learning in educational settings (Paavola et al., 2011). It explicates the central characteristics in the tasks and working methods to be designed for students in order to promote collaborative knowledge creation practices. The six Trialogical Design Principles (DPs) are the following:

DP1. Organising activities around shared objects: The first design principle emphasises arranging students' activities during courses so that they work on and improve tangible shared objects. These objects may be plans, reports, models, products, prototypes, etc. Work is advanced through cycles of collaborative planning, brainstorming, getting feedback, presenting and delivering/publishing.

DP2. Supporting integration of personal and collective agency and work through developing shared objects: Activities should be designed so that students' have to take responsibility for their own activity and learning as well as shared tasks and products, e.g., by responsibility roles in commenting or production of knowledge. At best the shared objects are such that their production combines individual goals with collective goals. 
DP3. Emphasising development and creativity in working on shared objects through transformations and reflection: The aim is to use working methods that help to solve complex problems where ideas and questions as well as practical and tacit knowledge are combined with conceptualisation, reflection and documentation. The phenomena are examined by using different forms of knowledge, such as theoretical models, practical examples, or process descriptions. Shared objects can be modified in various ways, such as by producing text, graphs and figures, or videos. Developing shared objects takes place iteratively, typically by producing, evaluating and revising several versions.

DP4. Fostering long-term processes of knowledge advancement with shared objects: The goal of long-term knowledge advancement is to deepen the understanding of examined phenomena and to develop products and practices that can subsequently be used for the participants or across individual courses and situations. For example, students may produce outcomes that are later used by customer organisations, a subsequent student group will be able to build on prior course materials, or the students themselves can use the work in later studies.

DP5. Promoting cross-fertilisation of knowledge practices and artefacts across communities and institutions:. Studying becomes more meaningful and educates working life skills when it includes questions, methods and expert practices from working life. The term crossfertilisation means collaboration between different communities and organisations, for example between educational institutions and companies, or between different units of the educational institution.

DP6. Providing flexible tools for developing artefacts and practices: To support the practices described by the other DPs, the tools should effectively mediate collective practices and development of shared objects as well as enable flexible mobility and collaboration in various representational forms. During multidisciplinary collaboration, it is important to agree on the use of various digital tools and services, and to learn how they can be used efficiently.

The trialogical DPs are quite general and meant to provide broad guidelines rather than detailed criteria or strict implementation guidelines for pedagogical design; they can be operationalised in many different ways in educational practice (Paavola et al., 2011). The DPs do not describe design aspects directly related to student learning; rather, they help educators to shape students' tasks and assignments towards activities that model cultural conventions of collaborative knowledge creation. This viewpoint relates to a sociocultural approach to learning, in which human activities and individual learning are seen as socially and culturally mediated, and the focus of pedagogical design is on intended activities rather than measurable learning results (Bell, 2004; Vygotsky, 1978).

\section{Aim of the study}

The core aim of the present study is to examine how the trialogical approach to learning could be used as a theoretical background in re-designing university courses through collaboration between university lecturers and educational researchers. The purpose was to advance collaborative knowledge creation practices as defined by the trialogical design principles, and to integrate knowledge work practices in the courses that are typical in current working life. The following two research questions were addressed:

(1) How did the changes that the lecturers made reflect the trialogical design principles?

(2) How did the lecturers and students participating in the re-designed courses evaluate the benefits and challenges of the course practices?

\section{Methods}

The overall methodological approach of the study is an application of design-based research (Bell, 2004; Design-Based Research Collective, 2003). Specific to design-based research (DBR) is that research, theory and practice are intertwined in the research and development efforts. In the present study, the researchers introduced the theoretical learning approach and the pedagogical design principles to the lecturers and supported them in operationalising the principles in their course contexts. The lecturers made the final decisions concerning their course designs. The researchers observed, documented and analysed how the lecturers operationalised the trialogical design principles into the reality of their university courses, and then examined how the lecturers and students evaluated the re-designed 
pedagogical practices. Figure 1 displays the overall structure of the design-based research endeavour of the study.

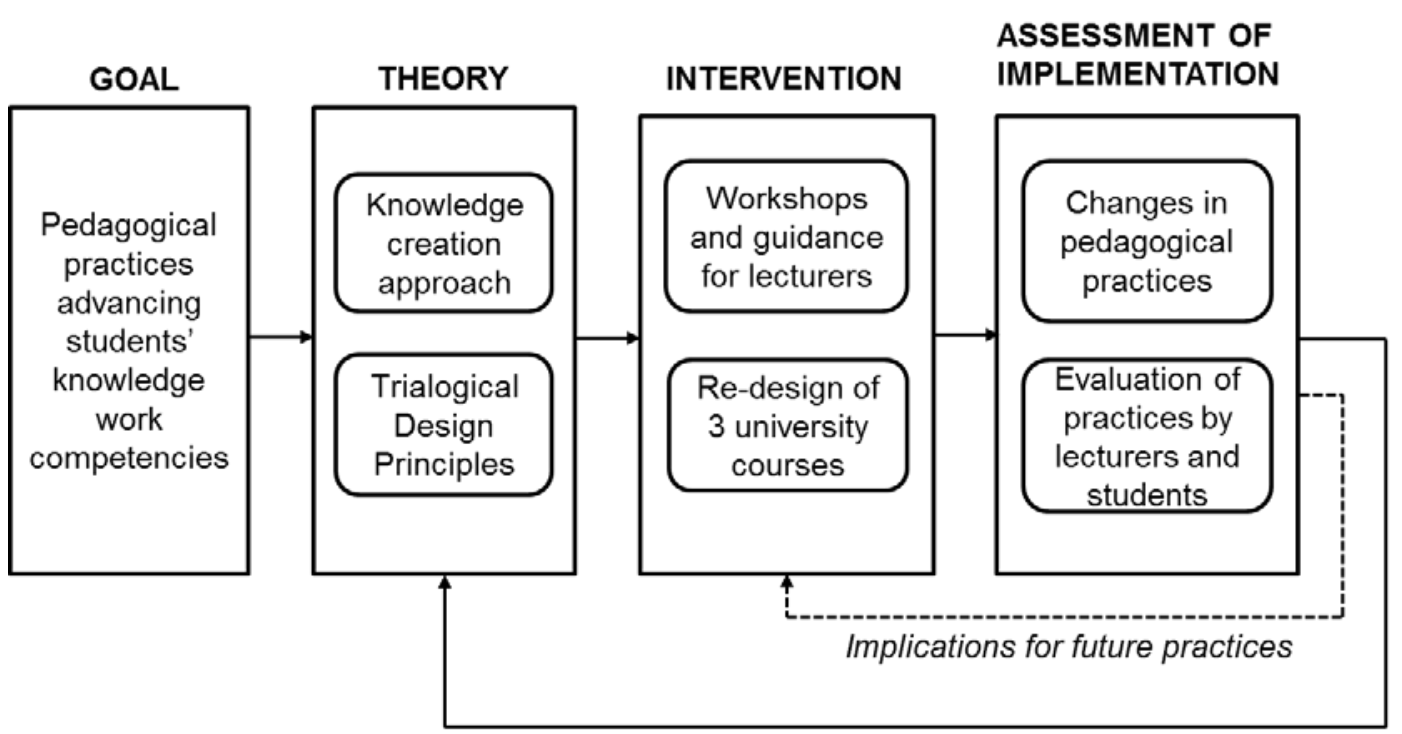

Implications for refining the design principles

Figure 1. Overall structure of the design-based research endeavour

The study covers one DBR cycle examining the application of trialogical design principles in the design of multiple university courses. Referring to the framework of McKenney and Reeves (2012), the main emphasis is on the evaluation and reflection of the implementations, conducted both through formative and summative means by exploring the course plans and actualised practices as well as by analysing participating lecturers' and students' self-reported course evaluations. Two of the investigated courses were re-designed iterations of existing courses, one was a new course. The focus is on examining the possibilities for implementing collaborative knowledge creation pedagogies in university education across individual courses and domains, while also taking into account the training of educational practitioners.

\section{Setting and participants}

The study belonged to a larger research and development project at a research-intensive university. Lecturers from various faculties voluntarily participated in a series of workshops (three half-day sessions) introducing them to the trialogical approach to learning and helping them implement its principles in their courses. The lecturers were guided to use the trialogical design principles in developing their course plans, and the revisions were discussed together with all workshop participants. Between the workshops, the participants developed their course plans further and received written feedback from the researchers. A wiki platform was used for sharing materials as well as for writing and commenting on the plans.

Lecturers of three courses volunteered their courses in the present study. The course plans of these courses were discussed and evaluated in a research interview before the implementation; this consultation from two researchers aimed to further develop the pedagogical practices towards the trialogical approach. The selected courses represented different domains (social, biological and educational sciences), were held for undergraduate students, used digital technology, and included collaborative knowledge creation assignments for students. The investigated course settings were as follows:

- Course 1 - Basics in teaching and learning (4 ECTS), Education: The goal of the course was to acquaint students with the basic theories of teaching and learning from the viewpoint of lifelong learning. The 7 week course was run entirely through the Web. In all, 44 students completed the course, which was targeted at non-degree students in the Open University. The course consisted of successive modules including various collaborative tasks: discussion about learning theories, creating new solutions to educational cases in virtual workshops, peer-reviewing educational plans, and crystallising educational golden rules. In addition, the students kept personal learning 
diaries. The principal lecturer supervised the whole process and group work, and a teaching assistant tutored the writing of learning diaries. A Moodle platform with wiki functionality was used for all course activities in a multifaceted way.

- $\quad$ Course 2 - Research methods course (3 ECTS), Social Sciences: The goals of the course were to learn to write a research plan and select research methods as part of a broader research process. The course was intended for international students at the beginning of their exchange studies. It was run by one lecturer. In all, 26 students completed the course. The practices simulated a process of creating a research plan in small groups. The course included weekly contact sessions over 7 weeks, consisting of group presentations and a poster session. Each student also wrote an individual learning diary. The Moodle platform was used for common activities, sharing materials and group communication. In addition, the groups prepared their plans, presentations and posters using a free choice of digital tools.

- Course 3 - Project work course (4-10 ECTS), Biosciences: The purpose of this new voluntary course was to provide students with opportunities to learn project work skills and apply theoretical knowledge in solving practical problems. The head lecturer organised the course with two assisting lecturers. Three student teams (15 students in all) carried out a customer project. An external expert gave students initial project work training. In the teamwork, the chairman and the secretary were replaced every 2 weeks. The students themselves decided how many study points they wanted to achieve and accordingly allocated time for the work. The course included three joint meetings, where the teams presented their work and received feedback from peer students, lecturers and clients. A wiki platform was used for common activities, the sharing of materials and group communication. In addition, the student groups took into use some cloud services (e.g., Google docs) for their co-authoring needs.

\section{Data collection}

Qualitative methods were used in data collection and analysis. In order to capture the complex phenomena of organising teaching in authentic settings, multiperspective qualitative data on the planning, implementation, and evaluation of each course were collected (see Table 1). Primary data sources were lecturer interviews and students' course evaluations:

- Lecturer interviews: The principal lecturers of each course were interviewed both before and after the courses. Also other faculty members (e.g., teaching assistant or senior lecturer) participated in some interviews. Both the pre- and post-interviews included a semi-structured interview with the same main questions for all, and a stimulated recall session (Lyle, 2003; Vesterinen, Toom, \& Patrikainen, 2010), using course materials (plans or course products) as mirror stimuli in the discussions. In the pre-interview, the questions and discussions focused on the pedagogical solutions of the course as well as the differences between the previous and new iterations. In the post-interview, the questions concerned the evaluation of the realised course (e.g., successful and unsuccessful elements, student collaboration, guidance, and usage of technology). The interviews lasted approximately $11 / 2$ hours. The interviews were audiotaped and transcribed verbatim. They were used to answer both research questions.

- Students' written course-evaluations: A post-questionnaire including open-ended questions was sent to the students by email. Altogether 42 students (55.7\%) responded. The answers to the following questions were used as data: (1) How would you characterise your overall experience of the course? (2) What has been positive or impressive about the course? (3) What has been challenging or disturbing about the course? (4) Other comments? Students' written course evaluations were used to answer research question 2.

To obtain an overview of the course designs and to enhance the interpretation of the primary sources, the following complementary data on the course contexts were collected: written course plans, the contents of the web-based environment of the courses (working spaces, discourse forums and folders, files and notes produced by the lecturers and students) and written observation notes from the contact sessions of Courses 2 and 3. 
Table 1

Data collected from the investigated courses

\begin{tabular}{|c|c|c|c|c|}
\hline & $\begin{array}{l}\text { Participants in } \\
\text { the lecturers' } \\
\text { pre-interview }\end{array}$ & $\begin{array}{l}\text { Participants in } \\
\text { the lecturers' } \\
\text { post-interview }\end{array}$ & $\begin{array}{l}\text { Students' } \\
\text { course } \\
\text { evaluations* }\end{array}$ & Complementary material \\
\hline Course 1 & $\begin{array}{l}1 \text { lecturer } \\
1 \text { teaching } \\
\text { assistant }\end{array}$ & 1 lecturer & $16(36 \%)$ & $\begin{array}{l}\text { Written course plan; } \\
\text { Database content from } \\
\text { Moodle. }^{* *}\end{array}$ \\
\hline Course 2 & 1 lecturer & 1 lecturer & $15(58 \%)$ & $\begin{array}{l}\text { Written course plan; } \\
\text { Written notes from the } \\
\text { observation of all } 7 \text { contact } \\
\text { sessions; } \\
\text { Database content from } \\
\text { Moodle. }\end{array}$ \\
\hline Course 3 & $\begin{array}{l}2 \text { lecturers } \\
1 \text { senior lecturer } \\
\text { in university } \\
\text { pedagogy }\end{array}$ & 2 lecturers & $11(73 \%)$ & $\begin{array}{l}\text { Written course plan; } \\
\text { Written notes from the } \\
\text { observation of all } 3 \text { contact } \\
\text { sessions; } \\
\text { Database content from wiki. }\end{array}$ \\
\hline
\end{tabular}

${ }^{*}$ Response rate in parenthesis

${ }^{* *}$ The course was entirely online, there were no contact sessions to be observed.

\section{Data analysis}

To address the first research question, the course designs and their relationship with the trialogical DPs were traced from the lecturer interviews. First, those excerpts of the interviews, in which the lecturers described the pedagogical design of the courses (tasks and activities, organisation of collaboration, usage of technology, guidance, assessment etc.), were chosen for detailed analysis. Second, the design solutions described in the excerpts were examined and interpreted through the six DPs, and a table was constructed that compared the solutions of the previous and re-designed practices. Other materials (course plans, observation notes, database contents) were used in a complementary fashion in addition to the interviews.

For the second research question about course experiences, a data-driven thematic analysis method (Braun \& Clarke, 2006) was applied for the lecturers' post-interviews (one for each course) and the students' written course evaluations. First, those excerpts of data where the participants described positive or successful and challenging or disturbing aspects of the course were chosen for detailed examination. From the lecturer interviews, 89 such excerpts, and from the students' written answers, 306 such excerpts were included in the analysis. Second, main analysis categories were created related to pedagogical aspects that the participants referred to in the excerpts, concerning both positive and disturbing evaluations. The lecturers' semi-structured post-interviews included explicit questions about the success of the course in general, student tasks, guidance practices, usage of digital tools, and the success of student collaboration, which provided a starting point for defining the main categories. In addition, based on the examination of both lecturer and student data, a few more categories were created. The following main analysis categories were used in the final analysis: general issues (quality of the course, general experience), structure (clarity, timetable), tasks (good and poor tasks), digital tools (usefulness, difficulties), guidance (instructions, amount and quality of support), collaboration (functioning of student groups, participation of members) and outcomes (what students produced and learnt). Third, after the excerpts were coded according to the main categories, sub-categories were created in a data-driven manner to reveal more concrete positive and disturbing aspects that the participants mentioned in evaluating the courses. The categories were revised through several iterative data examination phases, moving back and forth between the whole data set, the coded excerpts, and the categories produced, combining categories or creating new ones based on the increased understanding of the data (Braun \& Clarke, 2006). The first author carried out the first coding, which was then examined together with other researchers in data analysis sessions, where disagreements were discussed and changes made to the coding if needed. The idea of investigator triangulation was followed to guarantee the reliability and quality of the analysis procedures (Creswell \& Miller, 2000; Denzin, 1970). The main categories were quite self-evident, and the concrete sub-themes were very diverse and had quite small frequencies each; 
therefore, counting interrater reliability was not considered relevant. Detailed coding was performed using the Atlas.ti software (version 7.1.5).

\section{Results}

\section{Changes in the pedagogical designs of the courses}

Both in the pre- and post-interviews, the lecturers were asked to describe the changes made in the pedagogical solutions, compared to previous courses, informed by the trialogical approach. The lecturers took into account all six DPs when revising their course plans, but the interview findings indicate that for an individual course, some principles got more emphasis than others depending on the course context and goals. The most essential changes made in each course design are described in Table 2.

Table 2

Differences between the lecturers' previous and re-designed pedagogical solutions in each course

\begin{tabular}{|c|c|c|}
\hline & Previous pedagogical designs & New pedagogical design \\
\hline \multicolumn{3}{|c|}{ Course 1} \\
\hline DP1 & $\begin{array}{l}\text { Individual tasks and optional } \\
\text { collaboration online. }\end{array}$ & $\begin{array}{l}\text { Web-discussions and co-creation of teaching solutions in } \\
\text { groups online. }\end{array}$ \\
\hline DP2 & $\begin{array}{l}\text { Assessment and course } \\
\text { completion based on individual } \\
\text { tasks. }\end{array}$ & $\begin{array}{l}\text { Course completion required taking responsibility for } \\
\text { completing the group task in addition to individual tasks. }\end{array}$ \\
\hline DP3 & Mainly theoretical writing tasks. & $\begin{array}{l}\text { Both theoretical and applied tasks; reflection on group } \\
\text { activities and personal learning. }\end{array}$ \\
\hline DP4 & $\begin{array}{l}\text { Several unconnected tasks } \\
\text { without further use. }\end{array}$ & $\begin{array}{l}\text { Cumulative process from module to module; building on } \\
\text { the participants' professional background. }\end{array}$ \\
\hline DP5 & $\begin{array}{l}\text { Multidisciplinary group of } \\
\text { participants }\end{array}$ & $\begin{array}{l}\text { Multidisciplinary group of participants; applied tasks that } \\
\text { fostered sharing of expertise between the participants. }\end{array}$ \\
\hline DP6 & $\begin{array}{l}\text { Special web-based platform for } \\
\text { sharing teaching materials and } \\
\text { organising web-discussions. }\end{array}$ & $\begin{array}{l}\text { Versatile use of Moodle with special emphasis on } \\
\text { applying the wiki functionality for co-authoring in } \\
\text { groups. }\end{array}$ \\
\hline
\end{tabular}

Course 2

DP1 Individual knowledge creation tasks, short-term group discussions in contact meetings.

DP2 Some freedom to choose the topic of individual tasks. Assessment based on individual tasks.

\section{A group task to produce a research plan, an oral} presentation and a poster.

Research plan topics negotiated between group members; each member in turn responsible for taking care of timetables and group work. Assessment based on the evaluation of group products.

DP3 Several small tasks.

DP4 Tasks that mainly served the learning of course content.

DP5 The lecturer gave expert lectures about research methods.

DP6 Individual products shared through Moodle.
A complete working process with one large task conducted through several iterations and presentation modes; peer commenting on group presentations. Group products were used as training materials during the course.

Course practices modelled the process of making and presenting a real research plan.

Group products shared through Moodle; group work coordinated through discussion forums. Various applications used to create presentations.

\begin{tabular}{l}
\hline Course $3^{*}$ \\
\hline DP1 \\
DP2 $\quad \begin{array}{l}\text { In their previous courses the } \\
\text { lecturers had not allowed students } \\
\text { to choose the amount of work } \\
\text { they want to allocate for the } \\
\\
\text { course. }\end{array}$
\end{tabular}

Demanding project work conducted in teams; a real project plan produced for external customers. Students chose the project according to their interests and decided how many study points they wanted to achieve, and allocated efforts to group work accordingly. Assessment based on group activities and products. 
Integrating theoretical and applied domain knowledge as well as knowledge and skills about project work. Both the students, lecturers and customers evaluated the team outcomes repeatedly in meetings.

DP4

DP5 In their previous courses the lecturers had not used external experts as trainers of professional practices or clients.

DP6 The lecturers had not used the wiki platform before.
Team products created for real needs of the customers. Project work training from an external expert. Intensive collaboration with the customers.

Public wiki platform for sharing and coordinating the process. Student teams used various cloud services for their co-authoring needs.

${ }^{*}$ No previous iteration of this specific course; the lecturers had a desire to include a course educating project work in the curriculum of the faculty.

In Course 1, the major change was that the students produced solutions to educational problems collaboratively in small groups. In terms of the design principles, the lecturer emphasised collaboration on shared objects, transformation and reflection, and use of digital technology, but found it challenging to implement them in the present iteration. The lecturer preserved individual tasks in addition to collaborative ones, because she had some doubts about learning through collaborative activities. One reason for the cautiousness was that the course was run entirely online without any contact meetings, which creates difficulties for the organisation and guidance of collaborative activities. In the postinterview, the lecturer remarked that "It [learning diary task] occupied the tutor and took resources and I was not able to examine them myself. Students thought it as too tough to be done in addition to the discussion." In the subsequent iteration of the course, the lecturer is going to maintain the collaborative tasks and decrease the number of individual tasks.

In Course 2, the lecturer redesigned the course tasks as integrated group assignments instead of small individual and collaborative assignments. Changing the task to more comprehensive and iterative in nature reflected the emphasis on the design principles on collaborating around shared objects as well as transformations and reflection. For instance, the lecturer pondered DP1 in the pre-interview as follows:

Actually, what could be a reasonable, easily realisable shared object which they could develop together in groups and could produce; how could it be organised in such a way that ... What could be such an entity, instead of too many single tasks?

In the redesigned course, the tasks simulated professional research practices. The students planned, negotiated, presented and reflected on the various versions of the research plans together as they would do in authentic research work. Students got acquainted with the various phases and collaboration practices in this kind of process. The materials students produced were also used as learning materials during the course.

In Course 3, the whole course design was based on an assignment to produce a problem solution for an external customer. The lecturers gave relatively broad freedom for students to decide the effort and resources that they would invest for the course. The students worked in teams as well as in close collaboration with the lecturers and work life representatives throughout the course and made the evaluation of the work processes and outcomes together. Multiple types of technologies were used to support the work. Taken together, the course emphasised the design principles on collaborating around shared object, cross-fertilisation, and flexible tool use. The students had a possibility to learn how to complete an authentic task in collaboration with experts working in their own field.

\section{Teachers' evaluation of their re-designed courses}

The lecturers were asked in the post-interview to reflect on how the implementation of their course in a new form had succeeded. Figure 2 presents an overview of positive and negative issues mentioned by the lecturers, distributed in the main content categories. 


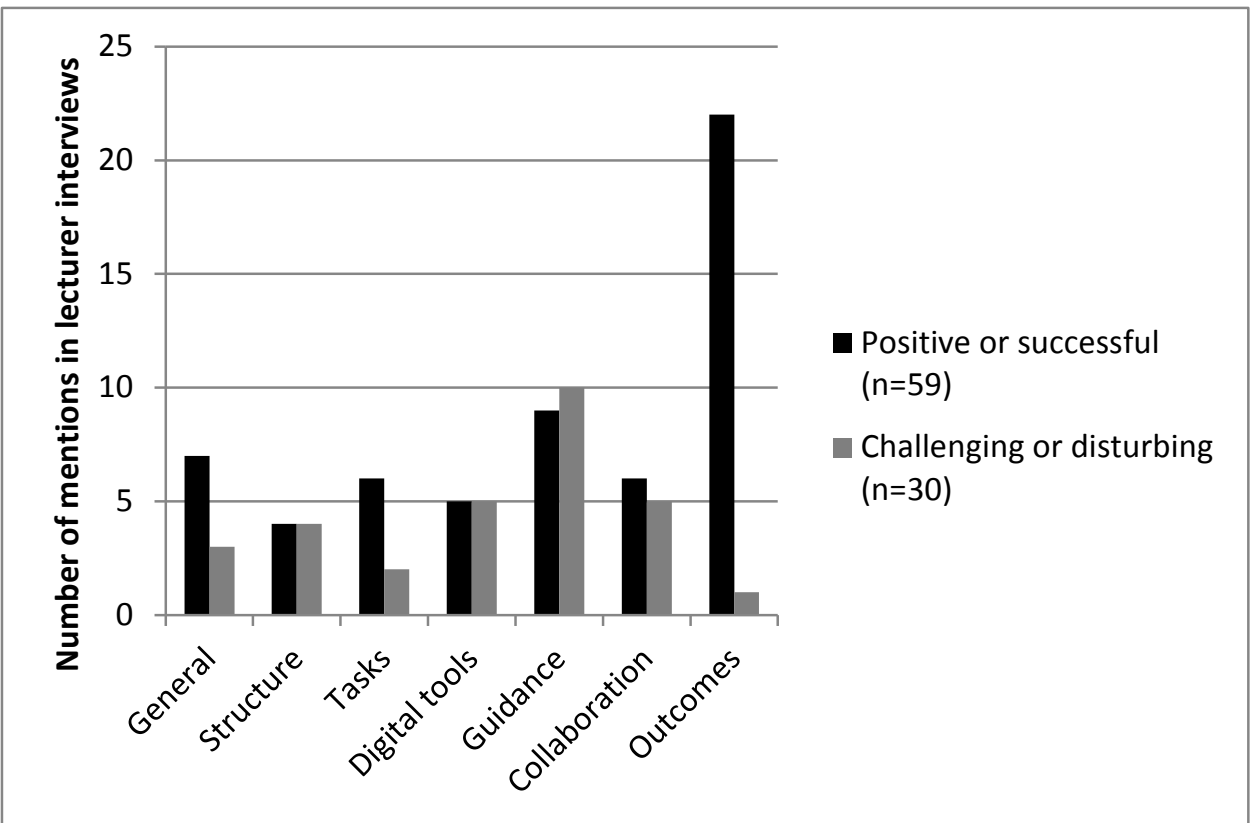

Figure 2. Lecturers' evaluation of the positive or successful and challenging or disturbing issues in the five courses.

Concerning general issues, positive remarks were made related to the satisfaction on the course in general and to the motivated attitude of students (Courses 2 and 3), and critical remarks related to the domain content (Courses 1 and 3). The implemented course structure was seen both as being supportive (in all courses) and sometimes too weak for students (in Course 1); also, the tight timetable was mentioned in negative terms concerning Courses 1 and 2. Lecturers of all courses mentioned some tasks that they considered being good (e.g., a poster walk in Course 2). In two courses some tasks were also seen as problematic, for example defining topics of the client assignments in Course 3.

Lecturers of Course 2 and 3 were mostly satisfied with the usage of digital tools, mentioning students' good ICT skills and appropriateness of tools; for example:

We had practically no problems with the wiki. The students were able to use it very well. We put there instructions and information about support persons whom they could contact, but I think that there were not any contacts taken. Thus, the wiki was quite functional. (Lecturer of Course 3)

Critical comments about tools addressed uneven student activity in digital forums (Courses 2 and 3), but especially the impracticality of Moodle in distance collaboration in Course 1 . In the interview, the lecturer expressed a desire to be able to use other social media applications in the future, because they would provide better affordances for co-creational activities.

All lecturers perceived strengths in the guidance practices, mentioning, for example, that the instructions were good (Courses 2 and 3), there was successful peer guidance (Course 1) or the clients were actively guiding the groups (Course 3). However they also saw room for improvements, for instance, in tailored guidance (all courses), or in the methods of supervising students' online activity (Courses 1 and 2).

The lecturers mentioned also the collaboration in student teams both in positive and negative terms. Individual satisfactory issues addressed were, e.g., open sharing (Course 1), multicultural teams (Course 2), and appropriate group size (Course 3). Shortcomings in collaboration related to some students' difficulties in group work and poorly organise teams (Course 1) or uneven participation in group work and too big teams (Course 2). For example: 
Perhaps, on the other hand, even though the students considered that the multicultural group work taught them a lot, and some believed that it will be explicitly useful for them in their future academic work, obviously there, however, were some problems. So, how could you still get the collaborative responsibility highlighted in the group? (Lecturer of Course 2)

The lecturers of all courses mentioned the outcomes of the learning process in positive terms (only the outcome of a self-reflection task in Course 1 was evaluated as unsuccessful). Most of the satisfactory outcomes were in line with the aims addressed by the trialogical design principles; students succeeded in doing a challenging task (all courses), high-quality final products (Courses 1 and 2), knowledge applicable in practice (Courses 1 and 2), students learnt team work (Courses 2 and 3), and students learnt professional practices (Courses 2 and 3). The lecturer of Course 3 evaluated the achievement of course goals in the following way:

I think that they were achieved really well in terms of group work and self-directness, also this [practice] that they were independently in contact with the client. Indeed, we assumed that these groups ask for help if they need, and I think that it succeeded well.

The lecturer of Course 1 was positively surprised that students succeeded in an ambitious and challenging collaborative knowledge creation task entirely through virtual means. She remarked that: "[T]hey took into use more theoretical tools in their plans than I had expected. They were of much higher quality than what a typical individual learning task answer would have been.”

\section{Students' evaluation of the courses}

Also the students were asked to evaluate the positive and impressive or challenging and disturbing aspects of the courses in a post-questionnaire. Their answers were analysed using the same main content categories as with teacher evaluations. Figure 3 shows an overview of positive and negative issues mentioned, distributed in the main content categories.

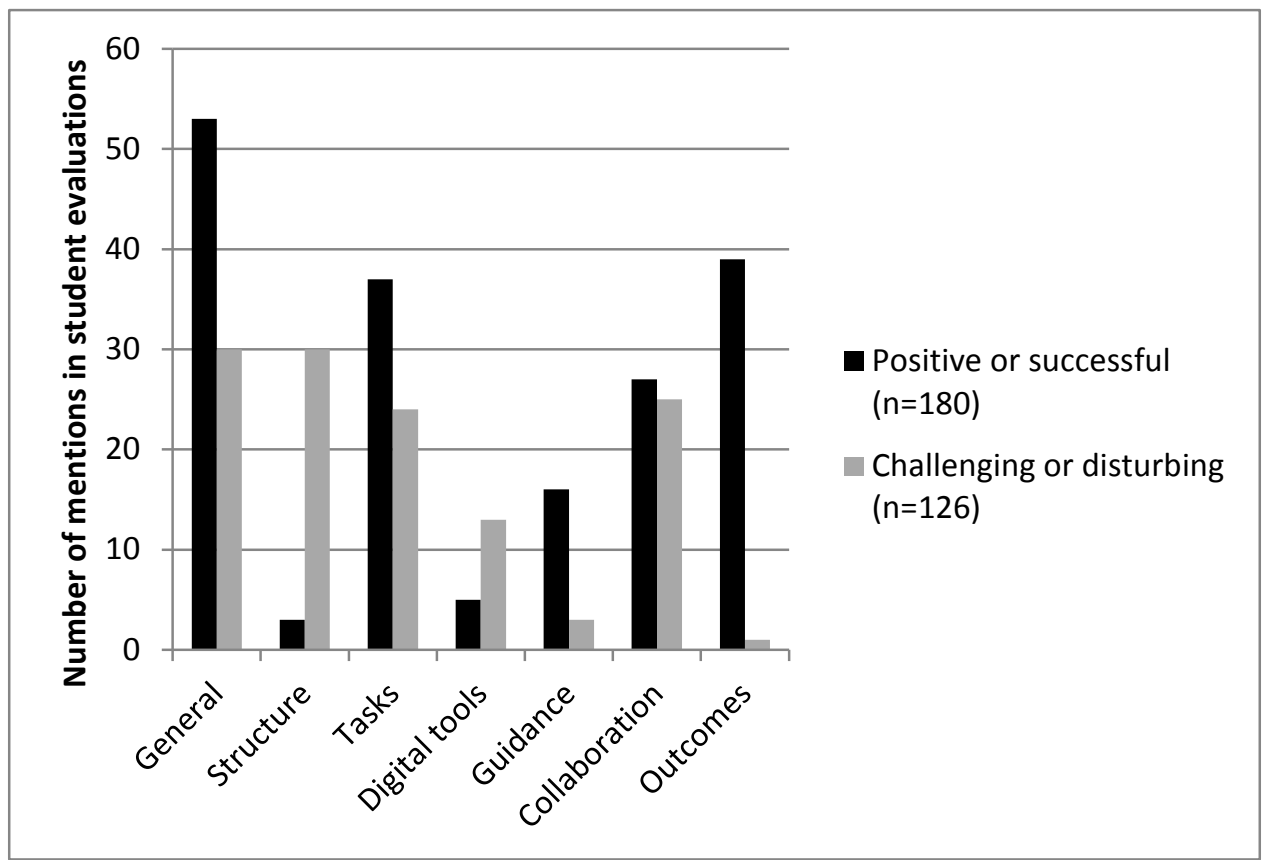

Figure 3. Students' evaluation of the positive or successful and challenging or disturbing issues in the courses.

Students' answers of all courses included many general statements praising the course experience, for example: "I was very pleased that I participated and was accepted in the course. The course was an awesome addition to otherwise very lecture-based courses. I liked it a lot.” (Course 3). The students also mentioned interesting content (all courses), comprehensiveness (Courses 1 and 2), educativeness (Courses 
1 and 3), good planning (Course 1) and fair workload (Course 2) of the courses. Critical comments about the courses related to weak theoretical content (all courses), laboriousness (Courses 1 and 3), weak own commitment (Courses 1 and 3), and negative overall experience (Course 1).

A few positive remarks about the course structure (good timetable, structuring of modules) came from Course 1. Critical comments included mentions about tight timetable (all courses) and confusing structure (Courses 1 and 3). Most of the criticism came from Course 1, especially about the large amount of parallel activities, assignments and deadlines, for example: "The timetable. Sometimes the deadlines were tight. I chose the tactic of keeping the deadlines of group tasks, but returning the individual tasks late.”

Concerning the tasks, students appreciated group work (all courses), real work processes and responsibility given for students (Course 2 and Course 3) as well as applied tasks (Course 1) and course tasks in general (Courses 1 and 2). However, collaborative tasks were also mentioned as being difficult (all courses), and a few students would have preferred individual studying (Courses 1 and 2). Some tasks were considered irrelevant or overlapping in all courses. Focusing the project work was experienced challenging in Courses 2 and 3. Below is an example of one positive and one negative remark from students in Course 3:

[Positive or impressive was] to see and experience how to start carrying out the project and how to initiate it in the first place.

Most challenging probably was that the employer could not make it clear what they really wanted and, first, we went into wrong direction in carrying out the project.

Digital tools received only a few comments from the students. Positive was online availability of materials (Courses 1 and 2) and reasonably good tools (Course 1). Critical issues related to the challenges of web-based communication (Courses 1 and 2) or unpracticality of tools and messy course area (Course 1). Guidance was mentioned mostly in positive terms, for example active support (Courses 1 and 3), good instructions (Courses 1 and 2) and guidance from the clients (Course 3). A few students would have like more guidance in Courses 1 and 3 .

The success of collaboration received mixed reactions from students as can be seen from Figure 3. Positive aspects in all courses were successful group work and communication with others. Participants' different viewpoints and getting to know other students was valued in Course 2. Critical remarks were mentioned about uneven commitment to group work and difficulties to find time for group meetings (all courses), ineffective collaboration at some points (Courses 2 and 3), and different backgrounds of participants (Course 2). The international and multidisciplinary setting in Course 2 produced extra challenges for group work but also created conditions for cross-fertilisation; for example:

That it was a mixture of different disciplines. It sometimes brought up difficulties but, overall, I found it interesting to get in touch with different perspectives and it reinforced the richness of discussion and research plans.

As with the lecturers, the outcomes of the courses received practically only positive evaluations from the students, like learning of more content knowledge (all courses), learning of expert practices and high quality group work results (Courses 2 and 3), knowledge applicable in practice (Courses 1 and 2), skills for real work life (Course 3), learning to work in teams (Course 2), and products useful for clients (Course 3 ). The only negative comment criticised the quality of some group presentations in Course 2.

\section{Discussion and conclusions}

The main results of the study are summarised addressing two questions:

- What kinds of changes did the university lecturers make in their courses when applying trialogical design principles? and

- How did the participants evaluate the benefits and challenges of the new pedagogical practices? 
Based on the results, some conclusions are made about how the trialogical approach of learning serves as a theoretical background in developing university education.

\section{Changes in the lecturers' pedagogical practices}

In developing the course designs, the lecturers emphasised some design principles as more relevant for their course than others, depending on their course context and goals. It might also be more feasible for instructors to start changing their pedagogical practices by, first, applying a few guiding principles rather than trying to change everything at once. As Scardamalia (2002) remarked, it is a different issue to accept the principles of a pedagogical innovation than to apply them immediately in teaching.

The shift in the characteristics of learning activity from completing small, individual assignments into producing large, collaborative outcomes succeeded well in Courses 2 and 3 where the assignment modelled professional working processes. In Course 1, it was more difficult for the lecturer to design a new type of shared object for the groups. It appears that the lecturer felt it challenging to give up the established course practices, and thus, ended up keeping both the old and the new assignments. This is understandable from the viewpoint of the lecturer wanting evidence on individual students' learning during the online course, but the investigated iteration resulted in a laborious course for the students.

The technological platform used in two courses was Moodle; it is a platform provided centrally by the university and widely used by lecturers in all faculties. Taking into use its functionalities in a more versatile way was a step forward for the lecturers, and the students also adopted other open cloud service tools on their own initiative. However, flexible and advanced use of modern web-applications in the courses would have required, first, more training for the lecturers and, second, more guidance on desired practices for the students within the courses.

As the study was intended to investigate authentic educational practices, the courses were not selected for research purposes; educators came to the training voluntarily with their own needs and visions, and the application of theoretical principles had to be adapted to their cases. Multiple iterations might be needed to assist the instructors develop, evaluate and re-design their courses, because the first implementation is usually not the best one for assessing the appropriateness of the applied theory. Course 3 was an entirely new course designed from scratch in collaboration with the lecturers and researchers. It was the only course that included organised collaboration with external experts (realising DP5) and creation of group products that were meant for real use in the customer organisations (realising DP4). The course did not carry a history of established pedagogical implementation and there was more freedom to make decisions about the participants, tasks, and tool use than in Courses 1 and 2. Thus, it might have been easier for the lecturers to apply the trialogical approach from a fresh perspective.

\section{Summary of the participants' evaluation of the re-designed courses}

Overall, both the lecturers and students participating in the investigated courses made more positive than negative remarks about the course practices. In all courses, the participants were very pleased with the outcomes of the study processes. Especially in Courses 2 and 3, in which the course design was based on one comprehensive, collaborative knowledge creation assignment, the positive outcomes that the students mentioned are well in line with the principles of the trialogical approach: the high quality of collaboratively made products as well as learning professional ways of working and team work skills. In Course 1, which included many tasks conducted individually in addition to collaborative assignments, the students mentioned only outcomes that concerned individual content learning.

Re-designing of the course practices created changes also in the assessment methods. In all courses, assessment was transformed from evaluating individual students by the lecturer towards peer-evaluation and assessment of group processes and products. It is noteworthy that the new ways of assessment did not create problems or negative feedback from students, which is promising from the viewpoint of transforming educational practices towards more co-creational activities.

Group work received mixed reactions in all courses: collaborative tasks were experienced as very rewarding but also challenging. Some problems with collaboration related to the social setting of the course (online setting in Course 1, or international setting in Course 2). The setting, its specific features 
and constraints, should always be taken into account when designing collaborative knowledge creation tasks and evaluating their success. A problem mentioned by students of all courses was the uneven commitment of group members. It is typical that some students commit to the collaborative tasks and activities, whereas others experience them negatively, preferring more independent self-studying (Cavanagh, 2011; Herrman, 2013). The students answered to the post-questions anonymously; therefore, we do not know in which group each respondent belonged to, but it appears that in all courses, some groups functioned better than others. Also the lecturers' reflections on the success of students' collaboration revealed that they particularly experienced difficulties in supervising and supporting problematic groups.

The problems encountered in group work do not necessarily indicate that the object-oriented knowledge creation assignments were not useful for the students. The study of Kapur (2008) demonstrated that students who first failed because of poorly-structured collaborative conditions, nonetheless outperformed their counterparts in subsequent well-structured conditions; the mere attempt to accomplish a challenging collaborative problem-solving task had taught them new competencies. Both the positive and critical evaluations from the students of the present study indicate that the courses indeed, created conditions for practicing collaborative knowledge creation and learning competencies required in current working life (Broussard et al., 2007; Tynjälä et al., 2006), as was the original goal of the intervention. When students have a double challenge to learn both new content and new working practices, they might experience that it would have been better to rely on traditional and familiar learning methods. However, the new methods are necessary to develop relevant competencies in knowledge work for the future. Instructors should take care that the challenges are at an appropriate level, and provide support in facing them. For instance, in Course 1 , the students felt that detailed instructions and active tailored guidance from the teacher were central success factors.

\section{Recommendations about using the trialogical approach in re-designing university courses}

The aim of the study was to investigate the implementation of the trialogical approach in different course contexts in university education. Although the trialogical design principles worked well as conceptual tools in pedagogical training and, subsequently, in designing, discussing and evaluating the pedagogical solutions, there are also issues to be addressed. As remarked by Paavola et al. (2011), the design principles are so broad that they could be interpreted in multiple ways, and this broadness might create pedagogical designs that are only loosely connected to the trialogical approach. In the investigated courses, the DPs stimulated changes at two levels: transforming specific sub-tasks into more co-creational (in Course 1) or changing the whole pedagogical idea of the course and the character of activities towards sustained, collaborative knowledge creation (Courses 2 and 3). In Courses 2 and 3, the students' assignments were organised to resemble authentic professional practices, which provided a good basis for implementing the trialogical design principles. Exposing students to expert-like knowledge work is a fundamental idea of trialogical learning. One recommendation for instructors implementing the trialogical approach is to create a meaningful, overarching object-oriented group assignment for the entire course duration, leaning on authentic professional working processes rather than artificial collaboration activities.

The challenges encountered in group work primarily relate to the implementation of DP2 (supporting the integration of personal and collective agency), which clearly requires new methods and innovative solutions in supervising group activities and promoting the commitment of all participants. Instructors should pay special attention in creating course practices that make individual accountability explicit as part of collaborative activity, like rotating responsibility roles in groups or making explicit agreements about individual commitments as was done in Course 3. Assessment should primarily be based on individuals' contribution to collaborative work, otherwise students' efforts might be strained by unrelated or competing objectives, that is individual versus collaborative tasks as in Course 1.

In using digital technologies for supporting collaborative knowledge creation (DP6), instructors should not rely on students' spontaneous appropriation of innovative tool use or co-creational activities through technology, but provide recommendations and models for effective practices. The usage of introduced tools should be part of required course assignments, not voluntary. 
An aspect not explicit in the DPs is the role of instructors: the design principles concentrate on modelling students' activities, they do not explicitly describe lecturers' contributions and their ways of acting in various phases of the course. For example, issues concerning process structuring and guidance, which are central in this kind of pedagogical design, are not addressed in the principles (compared for example, with the principles for authentic learning environments presented by Herrington and Oliver [2000]), but in the present study they emerged as aspects considered both by lecturers and students when they evaluated pedagogical practices. The results brought the matter up but do not yet provide clear solutions to be utilised elsewhere.

With this kind of pedagogical interventions with innovative instructors, it is possible to make relevant changes in pedagogical practices despite the fact that the development processes often progress slowly. The relevance of university students' competencies with the working life and surrounding society is crucial (Klusek \& Bernstein, 2006); therefore, it is necessary to continuously develop university education and investigate the developments. More research is still required to understand, e.g., the interplay between individual and collective accountability, or the learning of domain-specific knowledge and skills and the domain-generic knowledge work competencies targeted in our study.

The present study has its limitations because of the small number of investigated courses and only one round of design iterations. Three courses were selected in the analysis because these were the courses that we were able to follow and document most closely within the execution phase of the development project. A larger and more representative sample of courses from different domains and contexts would likely have generated more mixed responses both from teachers and students. In addition, the present findings report evaluations of course designs and experiences at the end of the courses; further research is needed to collect evidence on the learning of the targeted competencies and knowledge throughout a course and within separate student groups. To interpret our results, the redesigned courses received surprisingly positive evaluations already after the first redesign. In other circumstances, more iterations are likely needed to arrive at good and functional solutions, dependent on the context.

One factor influencing the reasonably high amount of positive comments could be that the lecturers participating in development projects often receive more support for reflecting on their course design and making pedagogical decisions; thus, they may escape some commonly recurring challenges in designing collaborative activities. Another factor might be that the topics and assignments that the lecturers had in mind already before the project, suited particularly well to the theoretical principles and related pedagogical ideas. This could have provided them a motivation to take part in the project in the first place.

Naturally, these aspects raise questions about whether the presented types of pedagogical practices are actually feasible on a larger scale or whether redesigning a course requires excessive time and support, beyond daily possibilities. As argued above, we consider the design principles as useful vehicles for change for teachers to set up pedagogical practices for cultivating students' competencies in collaborative knowledge creation.

As our results show, pedagogical re-design of courses through the trialogical design principles may take place on smaller task level or as comprehensive course restructuring. Even though more radical pedagogical change in a course design would produce better results in terms of students' competence learning, we think that it is worthwhile to transform pedagogical course practices even in a smaller scale and evaluate the functionality of the changes. Also major institutional-level changes in curricula and study programs are necessary in profoundly developing university education, but also individual lecturers themselves can advance the development of students' knowledge work competences by starting to develop their own courses first. Hopefully the introduced trialogical design principles evoke curiosity and the presented pedagogical course examples stimulate their application in educational practice.

\section{Acknowledgements}

We want to thank all students and teachers who participated in the investigation as well as all the persons who have helped improve the present article. The study was partially supported by the Network for Higher Education and Innovation Research at the University of Helsinki and partially by the European Commission (KNORK 402765 543154-LLP-1-2013-1-FI-KA3-KA). 


\section{References}

Bell, P. (2004). On the theoretical breadth of design-based research in education. Educational Psychologists, 39(4), 243-253. doi:10.1207/s15326985ep3904_6

Bell, P., Hoadley, C. M., \& Linn, M. C. (2004). Design-based research in education. In M. C. Linn, E. A. Davis, \& P. Bell (Eds.), Internet environments for science education (pp. 73-85). Mahwah, NJ: Lawrence Erlbaum.

Bereiter, C. (2002). Education and mind in the knowledge age. Hillsdale, NJ: Erlbaum

Braun, V., \& Clarke, V. (2006). Using thematic analysis in psychology. Qualitative Research in Psychology, 3(2), 77-101. doi:10.1191/1478088706qp063oa

Brooks, R., \& Everett, G. (2009). Post-graduation reflections on the value of a degree. British Educational Research Journal, 35(3), 333-349. doi:10.1080/01411920802044370

Broussard, S. R., La Lopa, Joseph M., \& Ross-Davis, A. (2007). Synergistic knowledge development in interdisciplinary teams. Journal of Natural Resources and Life Sciences Education, 36(1), 129-133. doi:10.2134/jnrlse2007.361129x

Buus, L. (2012). Scaffolding teachers integrate social media into a problem-based learning approach? Electronic Journal of e-Learning, 10(1), 13-22. Retrieved from http://www.ejel.org/volume10/issue1

Cavanagh, M. (2011). Students' experiences of active engagement through cooperative learning activities in lectures. Active Learning in Higher Education 12(1), 23-33. doi:10.1177/1469787410387724

Commission on Accountability in Higher Education. (2005). Accountability for better results: A national imperative for higher education. Boulder, CO: State Higher Education Executive Officers. Retrieved from http://www.sheeo.org/resources/publications/accountability-better-results

Creswell, J. W., \& Miller, D. L. (2000). Determining validity in qualitative inquiry. Theory Into Practice, 39(3), 124-131. doi:10.1207/s15430421tip3903_2Denton, H., \& McDonagh, D. (2005). An exercise in symbiosis: Undergraduate designers and a company product development team working together. The Design Journal, 8(1), 41-51. doi:10.2752/146069205789338315

Denzin, N. (1970). The research act in sociology. Chicago, IL: Aldine.

Design-Based Research Collective (2003). Design-based research: An emerging paradigm for educational inquiry. Educational Researcher, 32(1), 5-8. Retrieved from http://www.jstor.org/stable/3699927

Gibbs, G., \& Coffey, M. (2004). The impact of training of university teachers on their teaching skills, their approach to teaching and the approach to learning of their students. Active Learning in Higher Education, 5(1), 87-100. doi:10.1177/1469787404040463

Gilardi, S., \& Lozza, E. (2009). Inquiry-based learning and undergraduates’ professional identity development: Assessment of a field research-based course. Innovative Higher Education, 4(4), 245256. doi:10.1007/s10755-009-9109-0

Helle, L., Tynjälä, P., \& Olkinuora, E. (2006). Project-based learning in post-secondary education Theory, practice and rubber sling shots. Higher Education, 51(2), 287-314. doi:10.1007/s10734-0046386-5

Herrington, J. \& Oliver, R. (2000). An instructional design framework for authentic learning environments. Educational Technology Research and Development, 48(3), 23-48. doi:10.1007/BF02319856

Herrman, K. J. (2013). The impact of cooperative learning on student engagement: Results from an intervention. Active Learning in Higher Education 14(3), 175-187. doi:10.1177/1469787413498035

Kali, Y., Levin-Peled, R., \& Dori, Y. (2009). The role of design-principles in designing courses that promote collaborative learning in higher-education. Computers in Human Behavior, 25(5), 10671078. doi:10.1016/j.chb.2009.01.006

Kapur, M. (2008). Productive failure. Cognition and Instruction, 26(3), 379-424. doi:10.1080/07370000802212669

Klusek, L., \& Bernstein, J. (2006). Information literacy skills for business careers: Matching skills to the workplace. Journal of Business \& Finance Librarianship, 11(4), 3-21. doi:10.1300/J109v11n04_02

Knorr-Cetina, K. (2001). Objectual practice. In T. R. Schatzki, K. Knorr Cetina, \& E. von Savigny (Eds.), The practice turn in contemporary theory (pp. 175-188). London: Routledge.

Lakkala, M., Ilomäki, L., Paavola, S., Kosonen, K., \& Muukkonen, H. (2012). Using trialogical design principles to assess pedagogical practices in two higher education courses. In A. Moen, A. Mørch, \& S. Paavola (Eds.), Collaborative knowledge creation: Practices, tools, concepts (pp. 141-161). Rotterdam: Sense Publishers. 
Lindholm, H. (2011). Maisterit, farmaseutit ja lastentarhanopettajat työmarkkinoilla. Vuonna 2005 Helsingin yliopistossa ylemmän korkeakoulututkinnon, farmaseutin ja lastentarhanopettajan tutkinnon suorittaneiden sijoittuminen työmarkkinoille viisi vuotta tutkinnon suorittamisen jälkeen. Helsinki, Finland: Helsingin yliopisto, Urapalvelut. Retrieved from http://www.helsinki.fi/urapalvelut/materiaalit/maisterittyomarkkinoilla.pdf

Lyle, J. (2003). Stimulated recall: A report on its use in naturalistic research. British Educational Research Journal, 29(6), 861-878. doi:10.1080/0141192032000137349

Marton, F., \& Trigwell, K. (2000). Variatio est mater studiorum. Higher Education Research and Development, 19(3), 381-395. doi:10.1080/07294360020021455

Mills-Dick, K., \& Hull, J. M. (2011). Collaborative research: Empowering students and connecting to community. Journal of Public Health Management \& Practice, 17(4), 381-387. doi:10.1097/PHH.0b013e3182140c2f

McKenney, S., \& Reeves, T. C. (2013). Systematic review of design-based research progress: Is a little knowledge a dangerous thing? Educational Researcher, 42(2), 97-100.

Muukkonen, H., Kosonen, K., Marttiin, P., Vesikivi, P., Kaistinen, J., \& Nyman, G. (2013). Pedagogical design for knowledge creating inquiry in customer projects. Knowledge Management \& E-Learning, 5(3), 278-297. Retrieved from http://www.kmel-journal.org/ojs/index.php/onlinepublication/article/viewArticle/266

Muukkonen, H., \& Lakkala, M. (2009). Exploring metaskills of knowledge-creating inquiry in higher education. International Journal of Computer-Supported Collaborative Learning, 4(2), 187-211. doi:10.1007/s11412-009-9063-y

Paavola, S., \& Hakkarainen, K. (2005). The knowledge creation metaphor - An emergent epistemological approach to learning. Science \& Education, 14(6), 535-557. doi:10.1007/s11191-004-5157-0

Paavola, S., Lakkala, M., Muukkonen, H., Kosonen, K., \& Karlgren, K. (2011). The roles and uses of design principles for developing the trialogical approach on learning. Research in Learning Technology, 19(3), 233-246. doi:10.1080/21567069.2011.624171

Prince, K. J. A. H., van Eijs, P. W. L. J., Boshuizen, H. P. A., van der Vleuten, C. P. M., \& Scherpbier, A. J. J. A. (2005). General competencies of problem-based learning (PBL) and non-PBL graduates. Medical Education, 39(4), 394-401. doi:10.1111/j.1365-2929.2005.02107.x

Scardamalia, M. (2002). Collective cognitive responsibility for the advancement of knowledge. In B. Smith (Ed.), Liberal education in the knowledge society (pp. 67-98). Chicago, IL: Open Court.

Sfard, A. (1998). On two metaphors for learning and the dangers of choosing just one. Educational Researcher, 27(2), 4-13. doi:10.3102/0013189X027002004

Toom, A. (2012). Considering the artistry and epistemology of tacit knowledge and knowing. Educational Theory, 62(6), 621-640. doi:10.1111/edth.12001

Tynjälä, P., Slotte, V., Nieminen, J., Lonka, K., \& Olkinuora, E. (2006). From university to working life: Graduates’ workplace skills in practice. In P. Tynjälä, J. Välimaa, \& G. Boulton-Lewis (Eds.), Higher education and working life: Collaborations, confrontations and challenges (pp. 73-88). Amsterdam: Elsevier.

Vesterinen, O., Toom, A., \& Patrikainen, S. (2010). The stimulated recall method and ICTs in research on the reasoning of teachers. International Journal of Research \& Method in Education, 33(2), 183-197. doi:10.1080/1743727X.2010.484605

Vygotsky, L. S. (1978). Mind in society. The development of higher psychological processes. Edited by M. Cole, V. John-Steiner, S. Scribner \& E. Souberman. Cambridge, MA: Harvard University Press.

Corresponding author: Minna Lakkala, minna.lakkala@helsinki.fi

Australasian Journal of Educational Technology (c) 2015.

Please cite as: Lakkala, M., Toom, A., Ilomäki, L., \& Muukkonen, H. (2015). Re-designing university courses to support collaborative knowledge creation practices. Australasian Journal of Educational Technology, 31(5), 521-536. 